\title{
ISOLASI DAN IDENTIFIKASI JAMUR ENDOFIT PADA UMBI TALAS (Colocasia esculenta (L.) Schoot)
}

\author{
Fitria Dewi Sulistiyono* dan Siti Mahyuni \\ Program Studi Farmasi, Fakultas MIPA. Universitas Pakuan, Jl.Pakuan No. 1 Bogor \\ *e-mail: fitria.sulistiyono@unpak.ac.id
}

\author{
ABSTRACT \\ Isolation and Identification of Endofit Fungus in Taro Tubers \\ (Colocasia esculenta (L.) Schoot)
}

\begin{abstract}
Endophytic fungi are fungi the living and associated in plant tissue. Association the endophytic and host are mutualism. The ability of endophytic producing a secondary compound is an opportunity to be developed. The aims of this research is isolate and identify the types of endophytic fungi in tubers of taro. The methode used microscopis and macroscopis idetify. The result types of endophytic fungi in tubers of taro are Aspergillus, Sclerotium, Fusarium, Mucor and Rhizopus.
\end{abstract}

Keyword: Taro, Idetify, Endophytic fungi

\begin{abstract}
ABSTRAK
Jamur endofitik adalah jamur yang hidup dan berasosiasi di dalam jaringan tanaman inang. Asosiasi yang terjadi umumnya bersifat mutualisme. Kemampuan mikroorganisme endofitik memproduksi senyawa metabolit sekunder sesuai dengan tanaman inangnya merupakan peluang yang sangat baik. Pemanfaatan mikroorganisme endofit diharapkan dapat melestarikan tanaman inangnya yang membutuhkan waktu untuk tumbuh dan berkembang. Tujuan dari penelitian ini adalah mengisolasi dan mengidentifikasi jenis-jenis jamur endofit yang terdapat pada umbi talas. Metode yang digunakan adalah identifikasi secara mikroskopis dan makroskopis. Hasil identifikasi dengan pengamatan secara makroskopis dan mikroskopis diperoleh genus Aspergillus, Sclerotium, Fusarium, Mucor dan Rhizopus.
\end{abstract}

Kata kunci : Talas, Identifikasi, Kapang endofit

\section{PENDAHULUAN}

Mikroorganisme endofitik adalah mikroorganisme yang hidup dan berasosiasi di dalam jaringan tanaman inang. Asosiasi yang terjadi umumnya bersifat mutualisme. Kemampuan mikroorganisme endofitik memproduksi senyawa metabolit sekunder sesuai dengan tanaman inangnya merupakan peluang yang sangat baik (Petrini et al., 1992).

Mikroorganisme ini hidup bersimbiosis saling menguntungkan dengan tanaman inang, dimana mikroorganisme endofit mendapatkan nutrisi dari hasil metabolisme tanaman sedangkan mikroorganisme menghasilkan senyawa aktif berupa metabolit sekunder yang menjaga inang dari serangan penyakit
(Taechowishan, et al., 2005). Mikroorganisme endofit sebagai penghasil senyawa aktif berpotensi untuk dikembangkan sebagai produser bahan baku obat (Ezra et al., 2004).

Umbi talas (Colocasia esculenta (L) Scott) merupakan bagian yang mempunyai prospek pengembangan cukup cerah dan menguntungkan, sumber karbohidrat yang penting sebagai penghasil energi di daerah tropis dan sub tropis (Liu et al., 2006). Bagian tanaman talas berupa umbi berpotensi sebagai sumber karbohidrat yang cukup tinggi. Umbi talas sebagai makanan mempunyai nilai gizi yang baik karena selain terdapat karbohidrat juga terdapat lemak dan protein (Chairul dan Chairul, 2006). 


\section{METODE PENELITIAN}

\section{Bahan dan Alat}

Bahan yang digunakan pada penelitian ini yaitu umbi talas, medium PDA, medium MEA, dan Alkohol 70\%.

Peralatan yang digunakan yaitu oven, jarum ose, autoklaf, mikroskop, dan peralatan gelas lainnya.

\section{Pemilihan Sampel}

Sampel yang digunakan untuk mengisolasi jamur endofit adalah umbi talas segar, tidak berjamur, tidak berlendir, tidak berlubang dan tidak berbau.

\section{Sterilisasi Alat (Davet dan Rouxel, 2000)}

Peralatan gelas yang digunakan

(Erlenmeyer $250 \mathrm{ml}$, pipet ukur, tabung reaksi, cawan petri) disterilisasi menggunakan oven pada suhu $80^{\circ} \mathrm{C}$ selama 3 jam. Jarum ose dan pisau disterilisasi dengan cara pemberian alkohol $75 \%$ kemudian dibakar langsung pada api lampu spirtus saat digunakan.

\section{Pembuatan medium Isolasi}

Medium yang digunakan untuk isolasi jamur endofit dari beberapa umbi talas adalah medium PDA. Medium untuk identifikasi Jamur endofit adalah medium MEA. Semua media sebelum digunakan terlebih dahulu disterilisasi menggunakan autoklaf pada suhu $121^{\circ} \mathrm{C}$, tekanan $1 \mathrm{~atm}$ selama 20 menit. Setelah suhu media mencapai $40^{\circ} \mathrm{C}$, media dituang ke dalam cawan petri dan tabung reaksi untuk digunakan saat isolasi jamur endofit.

\section{Isolasi Jamur endofit (Ratnaningtyas et al., 2011)}

Isolasi jamur endofit dari beberapa jenis umbi talas dilakukan dengan metode tanam langsung. Beberapa jenis umbi talas yang tidak mengandung patogen (sehat) dipotong berukuran $1 \times 1 \mathrm{~cm}$ secara aseptis kemudian diinokulasikan pada medium plate agar PDA dan diinkubasi pada suhu ruang selama 3-5 hari hingga tumbuh miselium kapang.
Identifikasi jenis jamur endofit pada masing-masing umbi talas

Identifikasi jamur patogen dilakukan dengan menggunakan pengamatan makroskopis, yaitu melihat morfologi koloni dan miselium. Pengamatan koloni meliputi warna, elevasi dan bentuk sedangkan miselium meliputi warna. Pengamatan mikroskopis dilakukan dengan menggunakan mikroskop meliputi spora dan miselium kapang

\section{Analisis Data}

Data yang diperoleh dari isolasi dan identifikasi jenis-jenis jamur endofit kemudian dianalisis secara deskriptif menggunakan metode analisis Pitt and Hocking (1995).

\section{HASIL DAN PEMBAHASAN}

Isolasi jamur endofit umbi talas diperoleh dari umbi talas yang diambil dari kabupaten Bogor yaitu daerah Ciapus dan Tanah Baru. Berdasarkan hasil isolasi isolat jamur endofit umbi talas yang berasal dari daerah Bogor, diperoleh lima isolat. Masing-masing isolat mempunyai karakteristik yang berbeda berdasarkan warna koloni pada medium dan sifat tambahan secara mikroskopis. Perbedaan morfologi koloni dan mikroskopis dapat dilihat pada tabel dibawah ini (Tabel 1).

\section{Isolat 1}

Isolat 1 tumbuh pada media MEA dengan menghasilkan warna isolat bening pada pertumbuhan awal, dan isolat berubah warna mejadi kehitaman pada pertumbuhan hari ke-7, membentuk beberapa benang miselia yang tumbuh ke udara dengan ukuran $0,5 \mathrm{~cm}$ pada pertumbuhan hari ke-5, bagian tepi bergelombang, dan teksur seperti kapas. Pengamatan secara mikroskopis menunjukkan adanya hifa bersekat. Berdasarkan ciri secara makroskopis dan mikroskopis seperti yang tampak pada Gambar 1 dan mengacu pada Pitt and Hocking, 1995), maka dapat diketahui bahwa isolat 1 termasuk kedalam genus Asperghillus. 
Tabel 1. Morfologi koloni, morfologi mikroskopis dan identifikasi jamur endofit teridentifikasi dari umbi talas.

\begin{tabular}{|c|c|c|c|c|c|}
\hline Pengamatan & Isolat 1 & Isolat 2 & Isolat 3 & Isolat 4 & Isolat 5 \\
\hline & \multicolumn{5}{|c|}{ Koloni Pada Medium } \\
\hline Warna koloni & Putih & Putih & Putih & Putih & Putih \\
\hline Permukaan & Kapas & Kapas & Kapas & Kapas & Kapas \\
\hline Spora/ sporangium & $\sqrt{ }$ & $\sqrt{ }$ & - & - & $\sqrt{ }$ \\
\hline Bentuk & Bulat & Bulat & - & Bulat & Bulat \\
\hline \multicolumn{6}{|c|}{ Sifat tambahan } \\
\hline Radial & - & Ada & Ada & - & - \\
\hline Hifa & Berseptat & $\begin{array}{l}\text { Tidak } \\
\text { berseptat }\end{array}$ & Berseptat & $\begin{array}{l}\text { Tidak } \\
\text { Berseptat }\end{array}$ & Berseptat \\
\hline Genus & Aspergillus & Sclerotium & Fusarium & Mucor & Rhizopus \\
\hline
\end{tabular}
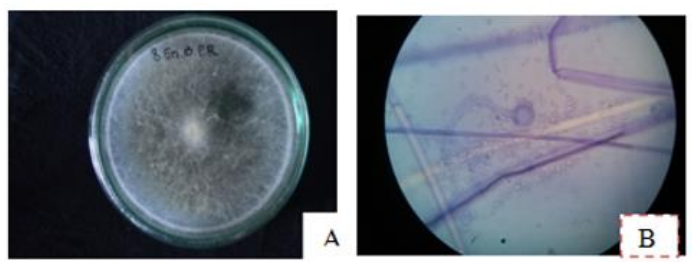

Gambar 1. (A) Koloni Aspergillus dalam medium MEA pada Masa inkubasi 7 hari dan

(B) Morfologi mikroskopis

Aspergillus secara mikroskopis menunjukkan adanya tangkai konidia (konidiofora), vesikel dan spora/konidia berbentuk bulat berwarna hijau kebiruan. Pemeriksaan mikroskopis menunjukkan adanya tangkai konidia (konidiofora) pendek halus berwarna kehijauan, kepala konidia (vesikel) berbentuk seperti gada (clavate) dan bulat, dan menjadi lonjong (columnar) dengan bertambahnya umur koloni. Sterigmata tampak menutupi setengah bagian atas dari vesikel. Spora/konidia berbentuk bulat, berwarna kehijauan, dan permukaan bergerigi (echinulate) (Redig, 2005).

\section{Isolat 2}

Isolat 2 tumbuh pada media MEA dengan menghasilkan warna isolat putih, bagian tepi rata, dan teksur seperti kapas. Sedangkan dari pengamatan secara mikroskopis tampak hifa tidak bersekat. Berdasarkan ciri secara makroskopis dan mikroskopis seperti yang tampak pada Gambar 2 dan mengacu pada Pitt and.
Hocking (1995), maka dapat diketahui bahwa isolate 2 termasuk kedalam genus Sclerotium.

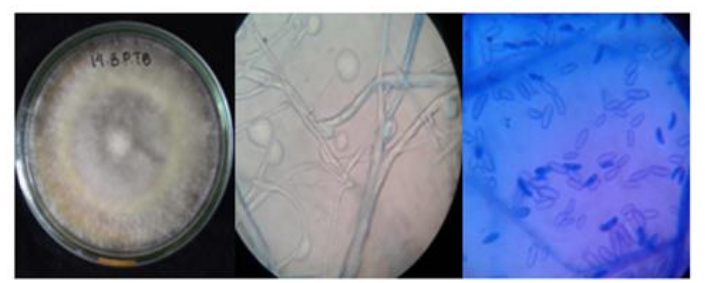

Gambar 2. (A) Koloni Sclerotium dalam medium MEA pada masa inkubasi 7 hari

(B) Morfologi mikroskopis

Karakteristik Sclerotium rolfsii membentuk koloni dengan miselium berwarna putih seperti kapas kompak dan padat. Perkecambah sklerotia berbentuk dispersif (hifa keluar dari semua sudut sklerotia) dan memiliki bentuk seperti kapas serta berwarna putih dengan ukuran diameter koloni yang terkecil $0,61 \mathrm{~cm}$ yang terlihat pada hari kedua dan ukuran terbesar $1,71 \mathrm{~cm}$ terlihat pada hari ketujuh (Magenda, 2011).

\section{Isolat 3}

Isolat 3 tumbuh pada media MEA dengan menghasilkan warna isolat putih, bagian tepi rata, dan membentuk radian lingkar. Sedangkan dari pengamatan secara mikroskopis tampak hifa bersekat, dan menghasilkan spora dengan bentuk oval. Berdasarkan ciri secara makroskopis dan mikroskopis seperti yang tampak pada 
Gambar 3 dan mengacu pada John I. Pitt and Ailsa D. Hocking (1995), maka dapat diketahui bahwa isolat En.J.P.C termasuk kedalam genus Fusarium.

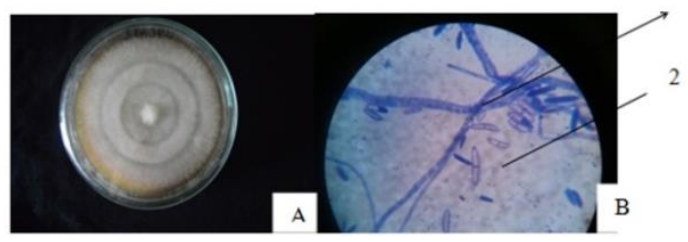

Gambar 3. (A) Koloni Fusarium dalam medium MEA pada masa inkubasi 7 hari

(B) Morfologi mikroskopis

(1) Hifa, (2) Spora

Fusarium memiliki bentuk miselium seperti kapas. Beberapa jenis Fusarium memiliki dua bentuk dasar konidia yaitu mikrokonidia dan makrokonidia, konidia berwarna transparan, dan bersepta. Secara mikroskopis marga tersebut dapat dikenali dari bentuk sporanya (makrokonidia) yang melengkung seperti bulan sabit dan memiliki sel kaki (pedicellate) yang jelas (Barnett and Hunter, 1998).

\section{Isolat 4}

Isolat 4 tumbuh pada media MEA dengan menghasilkan warna isolat putih, bagian tepi rata, dan teksur seperti kapas. Sedangkan dari pengamatan secara mikroskopis tampak hifa tidak bersekat, dan menghasilkan sporangium dengan bentuk bulat pada ujung hifa. Berdasarkan ciri secara makroskopis dan mikroskopis seperti yang tampak pada Gambar 4 dan mengacu pada (Pitt and Hocking, 1995), maka dapat diketahui bahwa isolat En.B.P.TB termasuk kedalam genus Mucor.

Mucor termasuk kedalam kelas Zygomycetes (perkembangbiakan secara seksual dengan zygospora yakni peleburan dua gametangium dan aseksual dengan spora yang diproduksi oleh sporangium). Secara makroskopis jamur ini seperti Rhizopus sp. yakni miseliumnya seperti kapas tetapi warnanya lebih putih dibandingkan dengan Rhizopus sp. dan secara mikroskopis jamur ini memiliki stolon tetapi tidak memiliki rhizoid dan sporangiofornya lebih pendek dibanding dengan Rhizopus (Pitt and Hocking, 1995).

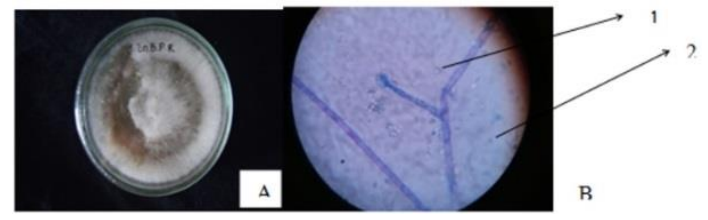

Gambar 4. (A) Koloni Mucor dalam medium MEA pada masa inkubasi 7 hari

(B) Morfologi mikroskopis

(1) Sporangium, (2) Hifa

\section{Isolat 5}

Isolat 5 tumbuh pada media MEA dengan menghasilkan warna isolat putih, bagian tepi rata, dan teksur tebal seperti kapas. Sedangkan dari pengamatan secara mikroskopis tampak hifa bersekat, dan menghasilkan sporangium dengan bentuk bulat pada ujung hifa. Berdasarkan ciri secara makroskopis dan mikroskopis seperti yang tampak pada Gambar 5 dan mengacu pada John I. Pitt and Ailsa D. Hocking (1995), maka dapat diketahui bahwa isolat B.S.TB termasuk kedalam genus Rhizopus.

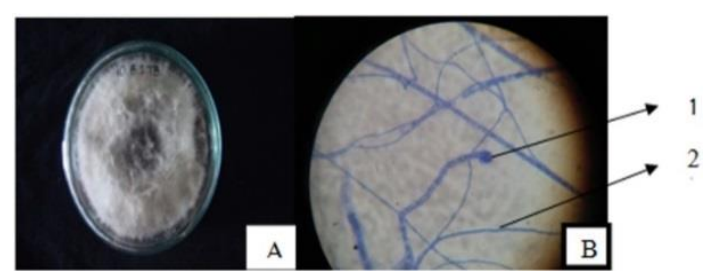

Gambar 5. (A) Koloni Rhizopus dalam medium MEA pada masa inkubasi 7 hari dan

(B) Morfologi mikroskopis

(1) Sporangium, (2) Hifa

\section{KESIMPULAN}

Hasil identifikasi dengan pengamatan secara makroskopis dan mikroskopis diperoleh genus Aspergillus, , Sclerotium, Fusarium, Mucor, dan Rhizopus.

\section{SARAN}

1. Perlu dilakukan identifikasi secara molekuler, dengan menggunakan 
daerah ITS (Internal Trancribed Spacer) ribosomal DNA (rDNA) untuk mengetahui nama ilmiah sampai species jamur endofit.

2. Perlu dilakukan uji lanjut mengenai pemanfaatan jamur endofit yang telah ditemukan pada umbi talas.

\section{DAFTAR PUSTAKA}

Barnett, H.L. \& Hunter, B.B. (1998). Illustrated Genera of Imperfect Fungi. 4th Edition. St Paul: APS Press.

Chairul, B. I \& Sofnie M. C. (2006). Isolasi glukomanan dari dua Jenis Araceae: Talas \{Colocasia esculenta (L.) Schott) dan Iles-Iles (Amorphophallus campanulatus Blumei). Jakarta: Pusat Penelitian Biologi-LIPI.

Davet, P. \& Rouxel, F. (2000). Detection and Isolation of Soil Fungi. Science Publisher.

Ezra, D., Hess, W. M.., \& Strobel, G. A. (2004). New endophytic isolates of Muscodor albus, a volatile-antibioticproducing fungus. Microbiology, 150 (12), 4023-4031.

Liu, Q., Donner, E., Yin Y., Huang, R.L., \& Fan, M. Z. (2006a). The physicochemical properties nd in vitro digestibility of selected cereals, tubers, and legumes grown in China. Food Chemistry, 99 (2), 470-477

Magenda, S., Kandou, F.E.F., \& Umboh, S D. (2011). Karakteristik Isolat Jamur Sclerotium rolfsii dari Tanaman Kacang Tanah (Arachis hypogaea Linn.). Jurnal Bioslogos, 1 (1), 1-7.

Petrini, L.E. (1992). Rosellinia species of the temperate zones. Sydowia, 44 (2), 169-281.
Pitt, J.I and A.D Hocking, 1995. Fungi and food spoilage.Third Edision. Academic Press, Australia.

Ratnaningtyas, N.I, Purnomowati, Mumpuni, A., Risyanto, S., \& Dewi, R.S. (2011). Petunjuk praktikum mikologi. Purwokerto: Universitas Jendral Soedirman.

Redig, P. (2005). Mycotic infections in birds I: Aspergillosis. North American Veterinary Conference Proceedings, Eastern States Veterinary Association 1192-1194.

Taechowisan, T., Lu, C., Shen, Y. \& Lumyong, S. (2005). Secondary metabolites from endophytic Streptomyces aureofaciens CMUAc130 and their antifungal activity. Microbiology, 151, 16911695. 